Revista Complutense de Historia de América

ISSN: $1132-8312$

http://dx.doi.org/10.5209/RCHA.64696

\title{
Los comisarios de distrito como recaudadores de impuestos en el mundo rural. Santa Fe (Argentina), en el tercer cuarto del siglo XIX
}

\author{
Evangelina de los Ríos
}

Recibido: 19 de enero de 2018 / Aceptado: 21 de enero de 2019

Resumen. El presente artículo indaga en los modos en que se efectuaba la recaudación en el mundo rural de Santa Fe en el tercer cuarto del siglo XIX. Se muestra cómo más allá de las intenciones de las autoridades provinciales por centralizar la colecta impositiva en la figura de los receptores de hacienda departamentales -tal como quedó plasmado en las diferentes reglamentaciones fiscales-, esta estuvo en manos de los comisarios de cada distrito en que se dividía la campaña. Se propone un acercamiento desde la experiencia cotidiana de estos agentes que revela sus dificultades a la hora de emprender dicha tarea. Las fuentes que han servido de sustento a este artículo son las notas y la correspondencia que los mismos receptores, comisarios de distrito y comisarios generales campaña mantuvieron, a lo largo del período, con distintas esferas de la administración provincial.

Palabras clave: Recaudación; fiscalidad; comisarios; Santa Fe; siglo XIX.

\section{[en] District Commissioners as Tax Collectors in the Rural World. Santa Fe (Argentina) in the third quarter of the $19^{\text {th }}$ century}

\begin{abstract}
These article inquires into the methods of tax collection in the rural sphere of Santa Fe in the third quarter of the 19th century. It demonstrates that, despite the provincial authorities' intentions of centralizing tax collection in the departmental receptors of the Treasury - as had been established in the different fiscal regulations - the process was in the hands of the commissioners of each of the districts created for the campaign. An approach is offered, from the perspective of the day-to-day experiences of these agents, which reveals the difficulties faced when trying to undertake this task. The sources that have served to sustain this article are the notes and correspondence that the receptors, district commissioners and general commissioners maintained, throughout the period, with the different levels of the provincial administration.
\end{abstract}

Keywords: Collection; Fiscality; Commissioners; Santa Fe; $19^{\text {th }}$ century.

Sumario. 1. Introducción. 2. Características generales de la campaña santafesina en la segunda mitad del siglo XIX. 3. Los comisarios de distrito como recaudadores de impuestos. 4. Las autoridades de campaña frente a la colecta impositiva. 5. Distancias y proximidades: diferentes miradas sobre la recaudación en el mundo rural. 6. Conclusión. 7. Referencias bibliográficas.

Cómo citar: De los Ríos, E. (2019) Los comisarios de distrito como recaudadores de impuestos en el mundo rural. Santa Fe (Argentina), en el tercer cuarto del siglo XIX, en Revista Complutense de Historia de América 45, 281-303.

1 Becaria Postdoctoral del ISHIR-CONICET/ CEHISO-UNR (Argentina).

E-mail: eddelosrios@hotmail.com 


\section{Introducción}

En las tres últimas décadas, la historia fiscal se constituyó en una de las temáticas que más atención ha recibido ${ }^{2}$. El caudal de investigaciones realizadas desde esta perspectiva aumentó copiosamente, volviendo más complejas las lecturas posibles de los procesos históricos. En este sentido, el análisis de la estructura fiscal del Imperio Español ha merecido la atención de numerosos especialistas, quienes vieron en la fiscalidad una puerta de entrada para indagar de forma integral los cambios y las continuidades que se sucedieron en el paso de la colonia a la república ${ }^{3}$. Recientemente el proyecto State Building in Latin América dirigido por Juan Carlos Garavaglia ha realizado significativos aportes al estudio de la formación del estado en América Latina en clave comparada a partir de la recolección pormenorizada de datos fiscales para el período $1820-1870^{4}$.

Para el caso rioplatense, las investigaciones mostraron como tras la ruptura del lazo colonial, la desarticulación el espacio peruano y las luchas al interior de las élites locales impactaron en el sistema fiscal ${ }^{5}$. Sobre la reconfiguración de las finanzas rioplatenses existen cuantiosas investigaciones ${ }^{6}$ que han demostrado las consecuencias económicas de la revolución ${ }^{7}$ y la continuidad tanto en la configuración de los vínculos mercantiles ${ }^{8}$ como en la pervivencia de los cuadros administrativos ${ }^{9}$. En los últimos años, los estudios se han focalizado en la situación particular de las finanzas de las distintas provincias. A partir del análisis de la economía, la estructura social y los vaivenes políticos se han analizado los fundamentos sobre los que construyeron sus sistemas fiscales y la conformación de sus administraciones ${ }^{10}$. Menos atención ha recibido el proceso de recaudación impositiva: cómo se cobraban los impuestos, quiénes eran los agentes involucrados en estas tareas y en qué ámbitos ejercían sus actividades son preguntas esenciales que contribuirían a echar luz sobre la historia fiscal ${ }^{11}$.

Los estudios sobre las finanzas de Santa Fe sin ser muy numerosos, sobre todo si los comparamos con la abundante historiografía que existe para otros casos provinciales, han relevado las cifras de la fiscalidad a partir de un análisis de los presupuestos y cálculo de recursos, planillas de ingresos y egresos y los fundamentos de los sistemas fiscales ${ }^{12}$. No obstante, el tema posee múltiples aristas aún no abordadas que merecen un análisis más profundo, por ejemplo, acerca del ejercicio de la colecta impositiva. Este problema presenta dos caras muy visibles: el examen de las distintas formas en que se cobraban los impuestos, por un lado, y un estudio detallado sobre quiénes eran estos recaudadores, por otro.

\footnotetext{
Los trabajos de Klein y Tepaske han sido muy ilustrativos al respecto. Ver: Klein - Tepaske, 1982.

Véase: Prados de la Escosura - Amaral, 1993; Coastworth, 1990; Bulmer-Thomas, 2003.

4 Dicho proyecto buscó un acercamiento a las formas y los ritmos el proceso de conformación estatal en los distintos casos americanos (Argentina, Chile, Colombia, Ecuador, la Banda Oriental, Costa Rica y Guatemala).

Un análisis al respecto: Klein, 1999; Amaral, 1984; Mariluz Urquijo, 1951; Lynch, 1967.

6 Los libros de Burgin (1960) y de Halperín Donghin (2006 [1985]) han sido la base de las investigaciones posteriores.

Schmit, 2010.

Tarragó - Caula, 2003.

Garavaglia, 2012.

Un estado de la cuestión en: De los Ríos, 2017a.

Gelman, 2010: 205

Véase: Bonaudo - Sonzogni, 1997; Chiaramonte - Cussianovich - Tedeschi, 1993; Ensinck, 1953; Gallo, 1965; Frid, 2011 y 2013.
} 
El presente artículo centra su análisis en la recaudación de impuestos en el mundo rural donde los comisarios de distrito -figuras centrales de la campaña- asumieron la tarea de recaudar los impuestos. Estos desempeñaban funciones judiciales, políticas, policiales y también fiscales. Esta situación no estuvo exenta de problemas: los reclamos de los mismos comisarios por la acumulación de ocupaciones y su desconocimiento a la hora de gestionar el cobro de impuestos, por un lado, y las quejas de los receptores de hacienda departamental, que no siempre conseguían que estos cumplieran con las obligaciones de la hacienda, por otro. Las distancias, la proximidad de los vínculos, las dificultades en la comunicación constituyeron temas recurrentes. Sobre estos ejes versa esta investigación.

Un análisis de la recaudación fiscal no puede comprimirse dentro de la órbita institucional o político-institucional. El abordaje de la administración estatal requiere estudiarse en su dinámica, su proceso histórico y social de conformación, prestando atención a los entramados de relaciones interpersonales que se tejen en su interior ${ }^{13}$. Por lo cual, no es posible medir su "eficacia" en el número de oficinas y de empleados de hacienda, ya que la "burocracia" estatal no era la única vía para cobrar impuestos $^{14}$. Una mirada a ras de suelo permite acercarnos a las prácticas cotidianas en torno a la recaudación fiscal y observar a los agentes que se hallaban en los escalones más bajos del entramado fiscal.

Esta investigación propone un acercamiento a las formas en que se cobraban los impuestos desde la perspectiva de los actores. Las fuentes que han servido de sustento a este artículo son las notas y la correspondencia que los mismos receptores, comisarios de distrito y comisarios generales campaña mantuvieron, a lo largo del período, con distintas esferas de la administración provincial. Estos documentos tenían como objetivo "lograr efectos políticos-administrativos en lugares distantes [...]"15. Su análisis permitirá conocer el modo de proceder de las autoridades de campaña y las dificultades que hallaban a la hora de recaudar. Al mismo tiempo, aporta información de primera mano sobre diferentes situaciones que se sucedían en el quehacer cotidiano: las quejas y frustraciones de los empleados, los problemas que debían enfrentar en torno a la colecta, los modos en que se entretejían las relaciones en estas dependencias y entre las autoridades locales con los demás vecinos del departamento.

\section{Características generales de la campaña santafesina en la segunda mitad del siglo XIX}

La provincia de Santa Fe situada en la margen derecha del río Paraná, se integraba en una extensa región denominada pampa húmeda y surcada por numerosos cursos de agua que la convertía en una pradera natural propicia para el desarrollo de acti-

\footnotetext{
Un estudio comparado sobre diferentes casos de América. Garavaglia, 2012.

14 Algunos trabajos han señalado la existencia de una "burocracia en las sombras" encargada de recaudar impuestos. Una de las muestras más clara de este proceso lo constituyen los arrendamientos de impuestos donde se "privatiza" la percepción. El fenómeno tiene una amplia tradición en la Hacienda hispánica del Antiguo Régimen (Véase: Alonso García, 2006) y también en la francesa -tal como lo ha mostrado J. Bosher (1970). Un cuidadoso análisis de la pervivencia de estas prácticas en la Banda Oriental en: Etchechury Barrera, 2013.

15 Hespanha, 1994: 131.
} 
vidades agrícola-ganaderas ${ }^{16}$. Se hallaba entonces dividida en cuatro departamentos -a saber, La Capital, Rosario, San Gerónimo y San José- que, a su vez, estaban subdivididos en distritos de campaña. Estos distritos se organizaron en torno al camino de postas que se tejieron en el territorio rioplatense a lo largo de los siglos XVIII y $\mathrm{XIX}^{17}$.

Hacia la segunda mitad del siglo XIX, Santa Fe vivió un proceso de transformación, intenso y muy rápido, impulsado por dos factores: la notable ampliación de su área productiva y el fuerte crecimiento poblacional. Si bien para 1853 contaban con una extensión territorial de $24.100 \mathrm{Km} 2$ aproximadamente, alcanzó para 1869 los $570.000 \mathrm{~km} 2$ y llegó a ocupar $1.158 .200 \mathrm{~km} 2$ para $1887^{18}$. De igual manera se multiplicó su población. En los diez años que median entre el Censo de la Confederación (1858) y el Censo Nacional (1869), el número de habitantes se duplicó -de 41.000 a $89.117^{19}$. La población se distribuía en algunos núcleos urbanos, principalmente la ciudad de Rosario, y un mundo rural en crecimiento. Como se observa en el Cuadro 1, en el ámbito rural el salto demográfico se acentúo en estos años y, aunque para 1887 el crecimiento urbano fue más notorio, la población rural volvió a duplicarse en menos de veinte años ${ }^{20}$. La posibilidad de contar con una gran disponibilidad de tierras y con una frontera abierta ofreció multiplicidad de oportunidades económicas y permitió el acceso a nuevos grupos, dando lugar a una rápida movilidad social en la región ${ }^{21}$.

Cuadro 1. Distribución urbano y rural de la población de Santa $\mathrm{Fe}^{22}$.

\begin{tabular}{|l|c|c|c|c|c|c|}
\hline & $\mathbf{1 8 5 8}$ & $\mathbf{\%}$ & $\mathbf{1 8 6 9}$ & $\mathbf{\%}$ & $\mathbf{1 8 8 7}$ & $\mathbf{\%}$ \\
\hline Urbano & 19.239 & $45,6 \%$ & 37.405 & $41,9 \%$ & 105.091 & $47,6 \%$ \\
\hline Rural & 22.022 & $53,4 \%$ & 51.712 & $58,1 \%$ & 115.241 & $52,3 \%$ \\
\hline Total & $\mathbf{4 1 . 2 6 1}$ & $\mathbf{1 0 0 \%}$ & $\mathbf{8 9 . 1 1 7}$ & $\mathbf{1 0 0 \%}$ & $\mathbf{2 2 0 . 3 3 2}$ & $\mathbf{1 0 0 \%}$ \\
\hline
\end{tabular}

Las autoridades provinciales consideraron necesario el poblamiento de la campaña como medio de reafirmar su soberanía sobre el territorio y superar así la fragmentación existente principalmente en relación con la fuerte presencia indígena en la frontera norte ${ }^{23}$. En el proceso de colonización santafesino, el modelo de expansión se caracterizó por el predominio de la articulación entre la propiedad de la tierra y la explotación familiar. En las treinta y ocho colonias fundadas entre 1856-1883, la organización de la producción giró alrededor de una unidad a cargo de propietarios

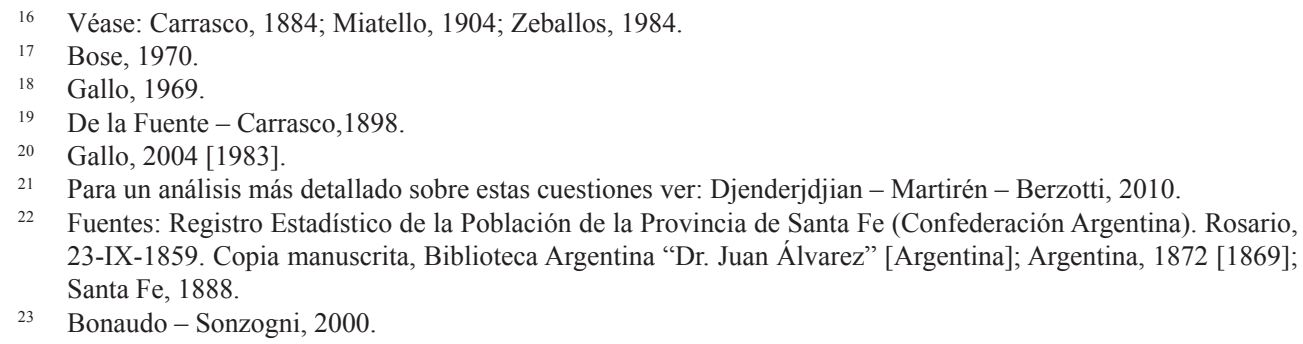


que contaron con el aporte del trabajo de la familia como factor primordial para su supervivencia y generar excedentes. Lo que caracterizó la colonización fue una articulación más explícita entre la propiedad, la familia y el propósito productivo que se le asignaba ${ }^{24}$.

A partir de la década de 1840, la campaña santafesina-que se hallaba completamente devastada a causa del paso de los ejércitos que aniquilaron la ganadería y arruinaron la producción ${ }^{25}$ - comenzó a mostrar signos de recuperación. Las estancias fueron lentamente repobladas y aumentaron su stock ganadero ${ }^{26}$. Al mismo tiempo, las autoridades provinciales tomaron una serie de disposiciones a favor de la agricultura $^{27}$. Sin embargo, la reanudación de las hostilidades contra Rosas volvía a convertir a Santa Fe en un campo de batalla donde las irrupciones de los ejércitos se sucedían de forma intermitente, especialmente en el sur donde el Arroyo del Medio separaba el departamento de Rosario de la provincia de Buenos Aires. En un contexto de marcado enfrentamiento, las fronteras se volvieron permeables y las incursiones de malones de indios -que arrasaban con el ganado y obstaculizaban el desarrollo de las actividades económicas en los distritos de campaña- eran moneda corriente ${ }^{28}$.

La integración a la Confederación Argentina (1852-1861) le abrió a la provincia nuevas perspectivas iniciando una década signada por fuertes transformaciones. A partir del quiebre de la política de exclusivismo comercial -que había mantenido Buenos Aires mediante el cierre de los ríos interiores-, Rosario se convirtió en el principal puerto para el comercio con mercados extranjeros ${ }^{29}$. Los cambios operados brindaron un considerable dinamismo al espacio rural, debido a la demanda de productos tanto para la exportación como para satisfacer el mercado local. Santa Fe sufrió un doble proceso: la incorporación de importantes porciones de territorio, por un lado, y el traspaso de tierras públicas a manos privadas, por el otro. Ambos factores volvieron a la campaña un polo de atracción de población, convirtiendo al pastoreo y, más tarde, a la agricultura en los propulsores de la economía. La economía santafesina logró un proceso de crecimiento centrado en la producción ganadera vacuna logrando incrementar su frontera productiva a partir del corrimiento de las fronteras, sobre todo hacia el norte, donde consiguió hacerse con el control de numerosas tierras. En esta coyuntura, crecieron los planteles ganaderos como resultado de la instalación de graserías y de saladeros ubicada a las orillas de Paraná ${ }^{30}$. Al mismo tiempo, diversos acontecimientos incidieron en la expansión de la agricultura en la campaña santafesina. El punto de partida lo marcó la fundación de la colonia de Esperanza. Las colonias representaron las primeras experiencias sistemáticas de producción cerealera mediante la labranza de unidades familiares, fuera de los contextos y prácticas tradicionales centradas en las estancias ${ }^{31}$.

Véase: Gallo, 2004 [1983].

25 Santa Fe sufrió cuatro intervenciones militares en su territorio entre 1815 y 1819. Véase Fradkin - Ratto, 2008. La situación no cambió en las décadas siguientes ya que la cercanía con Buenos Aires convertía a Santa Fe en un paso obligado de los ejércitos: la campaña de Lavalle contra Rosas (1840) y la invasión de los ejércitos al mando de Oribe (1842) constituyen algunos ejemplos. Iriondo, 1968. Para un análisis sobre la economía de Santa Fe en la primera mitad del siglo XIX: Tedeschi, 2010.

26 Un análisis sobre las transformaciones económicas durante estos años en: Frid, 2013.

27 ROSF, 1889, t. 1: 425; t. 2: 40.

28 Bonaudo, 2006.

29 Álvarez, 1947.

30 Frid, 2013.

31 Gallo, 2004 [1983]. 


\section{Los comisarios de distrito como recaudadores de impuestos}

En el mundo rural santafesino, comisarios de distrito y comisarios generales de campaña asumieron la tarea de recaudar los impuestos debido a que los receptores encontraban serias limitaciones para cumplir con este cometido. El departamento de Hacienda estaba integrado apenas por una Colecturía General, con sede en la ciudad capital, y sus dos históricas receptorías, una en Rosario y la otra en San Gerónimo. La Colecturía General -oficina encargada de regir las finanzas provinciales y elaborar los balances del tesoro público-y las receptorías -dependencia que centralizaban los ingresos departamentales, confeccionaba las listas de egresos y pagaba sueldos y demás gastos- contaban con una precaria composición, un verdadero inconveniente para el gobierno a la hora de gestionar los recursos ${ }^{32}$.

Junto a las carencias materiales que presentaban sus oficinas -reflejada a través de los diferentes inventarios ${ }^{33}$ - la falta de auxiliares en los cuales delegar algunas tareas, condicionaban el desempeño de sus funciones. Las receptorías no siempre contaban con escribientes o secretarios, apenas recibían la ayuda de los vigilantes de las partidas de plaza a quienes se les encomendaban labores como el reparto de guías, el traslado de documentos o de notas ${ }^{34}$. Una situación que no estuvo ajena a disputas. El escaso número de agentes que formaban las partidas - creadas para atender asuntos vinculados a la custodia de la ciudad y a la prevención de los delitos- hacía imposible prescindir de ellos para volcarlos a tareas administrativas ${ }^{35}$. Las oficinas tampoco contaban con servicios de caballos y postas, tan importantes a la hora de proceder a recaudar en espacios distantes. Muchas veces los receptores tomaban dinero de la caja departamental para costear este servicio o, cuando los fondos eran insuficientes, se veían obligados a pagar de sus propios bolsillos a algún vecino para que prestara su caballo; en otras, a falta de mejores alternativas, encomendaban a personas de su confianza -por lo general, comerciantes o viajantes que se desplazaban por el territorio- el traslado de papeles o notas ${ }^{36}$.

Pese a las intenciones del gobierno provincial de dejar en manos de los empleados de ese departamento todas las funciones de hacienda, la recaudación en el mundo rural continuó a cargo de las autoridades locales: los comisarios de distrito y los comisarios generales de campaña ${ }^{37}$. Se trataba de las máximas -aunque no las únicasautoridades del ámbito rural santafesino, en el que confluían también Comandantes de milicias y curas párrocos con quienes establecieron relaciones complejas que iban de la mutua colaboración al enfrentamiento directo.

32 Leyes y decretos, ceses y nombramientos comunicados por intermedio de la secretaria de gobierno al Colector D. Cayetano Echagüe. Santa Fe, 27-VII-1855. Archivo General de la Provincia de Santa Fe [Argentina] (en adelante AGPSF), Contaduría, t. 100, leg. 23, s/f.

33 La información volcada en los inventarios de estas oficinas brinda un panorama sobre las condiciones materiales en que los agentes actuaban tal como lo demuestran en diversos legajos del Fondo Contaduría del AGPSF.

34 De los Ríos, 2017a: 174.

35 Documentos varios. Rosario, 12-III-1855. Archivo Histórico Provincial “Dr. Julio Marc” (en adelante AHPJM), Jefatura política, t. $1855 \mathrm{C}, \mathrm{n}^{\mathrm{o}} 13$, s/f.

36 Notas del receptor de Coronda Don. Felipe Fernández al Contador Gral. D. José A. Lassaga. San Gerónimo, 16-XII-1852. AGPSF, Contaduría, t. 90, leg. 13, S/f.

37 Cada comisario era auxiliado por una Partida celadora de campaña cuya composición era independiente del número de población del distrito o la extensión de su jurisdicción, aunque fluctuaba en los diez soldados. Sobre la composición de las partidas celadoras de campaña en: De los Rios - Piazzi, 2013. 
Ahora bien, ¿cuáles eran las ocupaciones de los comisarios de distrito como recaudadores de impuestos? Las funciones que cumplieron eran múltiples: relevaban los registros de avalúo de la contribución directa y distribuían las células entre los contribuyentes ${ }^{38}$; confeccionaban los registros y repartían las papeletas para el pago de patentes. Además, controlaban el ganado del departamento mediante la preparación y actualización de los registros de marcas: al momento de proceder a la marca, cada propietario recibía una boleta en la que constaba el tipo y el número de su hacienda. El registro era utilizado por los jefes de policía, los jefes políticos y los jueces de paz para tener constancias de a quién pertenecía el ganado en caso de robo o extravío. Se ocupaban también de repartir las guías de comercio entre los conductores de tropas que circulaban y comercializaban en la campaña ${ }^{39}$. Asimismo inspeccionaban que los cueros destinados al marchamo contaran con el sello correspondiente que garantizaba la posesión del ganado o la guía que avalaba su compra ${ }^{40}$.

Junto a los impuestos instituidos en los reglamentos fiscales, recaudaban también otro conjunto de arbitrios: los denominados "eventuales de policía" (Véase Cuadro 2). Su particularidad radicaba en que se trataba de gravámenes que "están establecidos por la costumbre, y no habiendo ninguna ley en contrario, se ha continuado percibiéndolos $[\ldots]^{\prime \prime 41}$.

Tabla 4. Entradas eventuales de la Policía ${ }^{42}$.

\begin{tabular}{|l|l|}
\hline \multicolumn{1}{|c|}{ Entrada } & \multicolumn{1}{c|}{ Condiciones } \\
\hline Guías de extracción & $\begin{array}{l}\text { Impuesto a los troperos que llevaban ganado al interior. El despachante } \\
\text { debía contar con la guía -expedida en papel sellado de } 3^{\circ} \text { clase- y además } \\
\text { pagar 1\$ por cada 100 animales de su tropa y 1 real por cada peón. }\end{array}$ \\
\hline Guías de abasto & $\begin{array}{l}\text { Se cobraba al introducir ganado. La guía se expedía en papel de sello de } 5^{\circ} \\
\text { clase. También debía pagarse 2 reales a la policía por el visado cuando los } \\
\text { animales entraban a los corrales. }\end{array}$ \\
\hline $\begin{array}{l}\text { Papeletas de } \\
\text { conchavo }\end{array}$ & $\begin{array}{l}\text { Era un documento que debían porta todos aquellos no propietarios que } \\
\text { transitaban por la campaña con el que acreditaban su condición de peón de } \\
\text { una estancia y probaban que no eran "vagos"43. Los comisarios compraban } \\
\text { estas papeletas a 1 real por cada una y las expedían a 2 reales. }\end{array}$ \\
\hline Sellos de certificados & $\begin{array}{l}\text { Orden para legalizar cualquier pequeña transacción además de la compra } \\
\text { o renta de un caballo. Los comisarios compraban los certificados a 1 real y } \\
\text { los expedían a 2. }\end{array}$ \\
\hline
\end{tabular}

38 El Reglamento de Impuestos (1855) estableció que debían pagar contribución directa todos los poseedores de terrenos labrados de la provincia de más una cuadra cuadrada de superficie; los propietarios o criadores de ganado que poseían más de mil pesos en cualquier especie y los dueños de todo edificio. ROSF, 1889, t. 2: 298.

39 Instrucciones que deben servir a los comisarios generales de campaña, ínterin se sanciona el reglamento general de Policía. Rosario, 29-V-1855. AHPJM, Jefatura política, t. 1855 C, nº 13, S/f.

40 ROSF, 1889 , t. 3: 263 .

41 Informe del departamento de policía de Rosario sobre cobro de multas e impuestos que forman las entradas eventuales de policía. Rosario, 8-I-1863. AGPSF, Contaduría, t. 115, leg. 29, S/f.

42 Fuente: Informe del departamento de policía de Rosario sobre cobro de multas e impuestos que forman las entradas eventuales de policía. Rosario, 8-I-1863. AGPSF, Contaduría, t. 115, leg. 29, S/f.

43 Sobre la noción de "vago" ver: Alonso - Barral - Fradkin - Perri, 2001. 


\begin{tabular}{|c|c|}
\hline Entrada & Condiciones \\
\hline Pasaporte & $\begin{array}{l}\text { Era obligatorio para cualquier sujeto que quisiera pasar a otra provincia } \\
\text { contar con este papel donde constaba su nombre y el número de } \\
\text { caballos que llevaba, así como su propiedad y marca. Antes de emitirse } \\
\text { el pasaporte se debía vigilar que sus destinatarios no fueran peones } \\
\text { aconchabados y/o fugados, criminales o que trasportaran animales } \\
\text { robados. El precio de cada pasaporte variaba de acuerdo al número de } \\
\text { personas indicadas él. }\end{array}$ \\
\hline Permisos de baile & $\begin{array}{l}\text { Eran papeletas que autorizaban la realización de estas actividades por } \\
\text { un tiempo estimado. Los comisarios debían entregarlas formalmente por } \\
\text { duplicado. }\end{array}$ \\
\hline Permiso de caza & $\begin{array}{l}\text { Documento que permitía la realización de dicha actividad, según el tiempo } \\
\text { otorgado. }\end{array}$ \\
\hline $\begin{array}{l}\text { Gremio de } \\
\text { changadores }\end{array}$ & $\begin{array}{l}\text { Abono que pagaban los denominados changadores, peones dedicados a la } \\
\text { faena de cueros en la campaña. }\end{array}$ \\
\hline Marchamo de perros & Permiso que pagaban los dueños por cada perro. \\
\hline Matrícula & $\begin{array}{l}\text { Se trataba de un impuesto policial cobrado a los abasteceros de ganado o } \\
\text { bien a aquellos que tenían el derecho de carnear. Este impuesto era de } 10 \$ \\
\text { y se expedía por trimestre. }\end{array}$ \\
\hline $\begin{array}{l}\text { Guías de campaña y } \\
\text { de cueros }\end{array}$ & $\begin{array}{l}\text { Expedida en cada transacción comercial. Se realizaba en papel de sello, } \\
\text { o en papel ordinario que luego debía ser reemplazado en el pueblo, por el } \\
\text { que se cobraba } 2 \text { reales por el visado }\end{array}$ \\
\hline $\begin{array}{l}\text { Boletas o señas de } \\
\text { máscara }\end{array}$ & $\begin{array}{l}\text { Constituían boletas que se expedían por el uso de máscaras. Se pagaban } \\
\text { dos reales cada una. }\end{array}$ \\
\hline Multas de policía & $\begin{array}{l}\text { Cobradas por cada contravención que regía en el Reglamento de Policía } \\
\text { urbana y Rural. Eran anotadas en el libro de multas bajo la supervisión del } \\
\text { jefe de policía o el comisario de órdenes. }\end{array}$ \\
\hline
\end{tabular}

En la recaudación de los eventuales de la policía se contemplaba que una porción de la colecta quedase en manos de los comisarios como compensación ${ }^{44}$. Estos no percibían ningún tipo de salario por sus labores, lejos de constituir una forma de conseguir ingresos estables, representaba una carga pública que algunas veces resultaba ingrata, ya que para muchos significaba el abandono de sus negocios privados. Además, los beneficios que podían obtenerse, era posible perderlos con los numerosos cambios de gobierno. Por lo tanto, los vecinos nombrados se rehusaban a detentarlo por largos períodos de tiempo, obligando a continuos recambios ${ }^{45}$. La discusión sobre la percepción de sueldos de los comisarios se constituyó en uno de los principales ejes de debate al interior del recinto legislativo donde el mismo gobernador instó a los legisladores a recompensar con un sueldo las tareas que cumplían las autoridades de campaña ${ }^{46}$. Los

44 ROSF, 1889, t. 1: 243.

45 Notas de los jueces de paz de esta provincia. Carcarañá, 10-I-1860. AGPSF, Gobierno, t. 20, leg. 15, ff. 555.

46 "Mensaje del Sr. Gobernador de la Provincia de Santa Fe, Dr. Simón de Iriondo, a la Honorable Cámara de Representantes en la apertura de sus Sesiones Ordinarias el 21 de mayo de 1871". Comisión redactora de la Historia de las instituciones de la provincia de Santa Fe, 1972: 287. 
argumentos a favor de remunerar estos cargos provenían de la pluma de los mismos receptores, quienes señalaron como una de las dificultades que hallaban para conseguir que los comisarios cumplieran con las tareas fiscales radicaban en que estos no contaban con un salario: "Comprendo señor que esos hombres no quieran servir, estan cansado y siendo impagos dicen 'no tengo responsabilidad' al mismo juez de paz autoridad para ellos más caracterizada, puedo asegurar à VS que también le desatienden en cuento les place $[\ldots]^{\prime 47}$. Se creía que poco podían exigir si no les brindaban una remuneración, por lo cual se consideró prudente destinar una parte de lo percibido como incentivo para que cumplieran debidamente con estas labores. De lo recaudado como eventuales, los comisarios recibían un real por cada papeleta de conchavo, guía de campaña, sellos en certificaciones y una porción de cobrado de las multas. Un emolumento que resultó insuficiente.

\section{Las autoridades de campaña frente a la colecta impositiva}

Las funciones de los comisarios como recaudadores de impuestos representaron una fuente de continuos reclamos. La multitud de labores que debían desempeñar y su escaso conocimiento para realizar las tareas fiscales se convirtieron en los principales motivos de disputas entre distintas esferas de gobierno provincial.

\subsection{Vigilar, gobernar, controlar... y también recaudar impuestos: las funciones de los comisarios de distrito}

Las autoridades de campaña concentraban un número importante de funciones tanto políticas como policiales y judiciales. Los comisarios de distrito se ocupaban, entre otras cosas, de recorrer el distrito para perseguir y apresar criminales, desertores, vagos y "mal entretenidos" var disposiciones acerca del juego; regular el funcionamiento de pulperías, la caza de animales y el uso de $\operatorname{armas}^{49}$. La recarga de atenciones provocó que la recaudación de impuestos resultara una carga pesada de soportar y fueran relegadas a segundo plano o, en el mejor de los casos, se ejecutaran por fuera de los plazos establecidos en las leyes fiscales ${ }^{50}$. Los retrasos provocaron todo tipo de tropiezos: así, por ejemplo, las planillas de ingresos departamentales que debían remitirse a comienzos de cada mes llegaban a manos del receptor dos o tres meses más tarde al igual que las cuentas de gastos a cubrir, dilatando así su liquidación.

Al mismo tiempo, los comisarios encontraron idénticas limitaciones que los empleados de las receptorías a la hora de recaudar en la campaña y solicitaron, como condición para desempeñar las labores de hacienda, ser dotados con los caballos necesarios para alcanzar "hasta el último rincón de su distrito" 51 . Sin embargo, la falta de respuesta obligó a plantear otras alternativas. Entre las propuestas se contempló

\footnotetext{
47 Notas y cartas del receptor de San Gerónimo, José María Torres, al contador Gral. durante todo el año 1864. San Gerónimo, 18-I-1864. AGPSF, Contaduría, t. 117, leg. 20, S/f.

48 Un detallado análisis del concepto "mal entretenido" en: Barral - Fradkin - Perri, 2007.

49 Instrucciones. Rosario, 18-III-1855. AHPJM, Jefatura Política, t. 1855 B, nº 3, S/f.

50 Comisarios de distrito. Arroyo del medio centro, 18-IV-1860. AHPJM, Jefatura Política, t. 1860 A, n 4, S/f.

51 Notas de la receptoría de San Gerónimo al contador Gral. dirigidas durante el último cuatrimestre de 1862. San Gerónimo, 17-XII-1862. AGPSF, Contaduría, t. 110, leg. 55, S/f.
} 
la posibilidad de que fueran los Comisarios Generales de campaña los encargados de distribuir las guías, el papel sellado y las patentes - quienes, a diferencia de los comisarios que ejercían poder sobre un distrito, tenían jurisdicción en todo el departamento ${ }^{52}$. Contaban con la ventaja de no hallarse vinculado a ningún distrito. Además, por no ser vecinos ni propietarios del lugar donde ejercían su cargo se estimaba estarían menos influenciados por los intereses locales. La medida fue pronto desestimada. La renuencia de los Comisarios Generales, sobrepasados por sus propias obligaciones, fue respaldada desde el Ministerio de gobierno que se opuso a delegar estos ramos argumentando que la intención de las autoridades provinciales era concentrar estas actividades en agentes del departamento de hacienda y, hasta tanto no fuera posible, se ocuparían los comisarios de distrito ${ }^{53}$.

En pos de aliviar las tareas de los comisarios se tomaron algunas decisiones. Se nombraron Comisiones -integradas por vecinos respetables del lugar- para desempeñar algunas labores que, por diferentes motivos, los oficiales de hacienda se veían imposibilitados de cumplir como elaborar los registros de avalúo de la contribución directa, clasificar las patentes, confeccionar las listas de deudores del fisco, formar las planillas de ventas de tierras fiscales ${ }^{54}$, así como también inspeccionar, examinar y liquidar todas las cuentas de las cajas de cada oficina. Sin embargo, estas medidas no consiguieron aliviar las tareas de las autoridades rurales. Los comisionados solicitaron de forma continua la colaboración de los comisarios para realizar los registros de avalúo, distribuir las cédulas y avisar a los vecinos sobre los plazos para concurrir a las oficinas a cancelar sus deudas ${ }^{55}$. Estas peticiones mostraron las limitaciones de las comisiones para cumplir con las tareas asignadas, volviéndolas irrelevantes.

Otra medida fue el nombramiento de recaudadores de rentas fiscales para cada departamento. El objetivo central era mejorar la percepción de aquellas contribuciones que resultaban más difíciles de cobrar (la contribución directa y las patentes). Además, se esperaba que los recaudadores se ocuparan también de perseguir a todos aquellos que no cumplieran con sus obligaciones fiscales. Por lo cual, se los autorizó a proceder al embargo de propiedades u otro tipo de bienes, en el caso de que las intimidaciones de pago no fuesen debidamente cumplidas. Los objetos embargados debían ser vendidos en pública subasta y la suma obtenida de los remates ingresada a las cajas del erario provincial ${ }^{56}$. Las exigencias a los comisarios sólo eran aliviadas en parte, ya que el reglamento establecía que, en caso de que los contribuyentes se rehusasen a cumplir con sus compromisos, se debía solicitar su colaboración al momento de cobrar los impuestos. Esta situación ponía en entredicho la figura de

52 El comisario general se ocupaba de amonestar y corregir a los comisarios de distrito que no cumplieran con sus deberes, pudiendo incluso removerlos de sus cargos de considerarlo necesario. Estos estaban supeditados en su accionar al Jefe Político - en el departamento Rosario- y a los jueces de paz en los restantes departamentos. "Instrucción a los Comisarios generales de campaña, interín se sanciona el reglamento general de policía". Rosario, 29-V-1855. AHPJM, Jefatura Política, t. 1855 C, nº 13, S/f.

53 Notas de la receptoría de San Gerónimo al contador Gral. dirigidas durante el último cuatrimestre de 1862. San Gerónimo, 15-IX-1862. AGPSF, Contaduría, t. 110, leg. 55, S/f.

54 Como se ha señalado, la expansión territorial dejó en manos de las autoridades provinciales una inmensa extensión de tierras disponibles que se pusieron a la venta. La venta de tierras fiscales se convirtió en el principal recurso fiscal del estado. A lo largo de los '50s. representó el 50\% de los ingresos de Santa Fe. Informe de la Comisión del presupuesto y la ley de impuesto, Mensajes de los Gobernadores en: Comisión redactora de la Historia de las instituciones de la provincia de Santa Fe, 1972: 116.

55 ROSF, 1889, t. 2: 375 .

56 Ibídem, t. 5: 114. 
los recaudadores, cuya presencia fue pronto reconsidera. Tres factores fueron determinantes: en primer lugar, la resistencia de los pobladores de la campaña a pagar sus impuestos a estos empleados, a quienes cuestionaban su autoridad. Segundo, los llamados continuos a los comisarios para que los auxiliaran en el desempeño de sus tareas pronto inclinó la decisión a favor de suprimir estos puestos. Por último, lo oneroso que resultaba para las finanzas provinciales. El sueldo de estos recaudadores era superior a lo percibido por los receptores departamentales. Un gasto excesivo que no reportaba los beneficios esperados ${ }^{57}$. Un año después de los nombramientos, la Legislatura daba marcha atrás con el proyecto y resolvía suprimir estos cargos dejando, una vez más, la tarea de recaudar en mano de los comisarios ${ }^{58}$.

\subsection{El desconocimiento en el desempeño de las tareas fiscales}

El principal argumento que esgrimían los habitantes de la campaña para rehusarse a aceptar la designación como comisario de distrito era su falta de pericia para cumplir con los requerimientos que traía aparejado el puesto. Así, por ejemplo, José Rivas declinaba su nombramiento como comisario de Arroyo del Medio afirmando ser: "huna persona rustica é inorante, y siendo así como podre desenpeñar debidamte huna comision $\mathrm{q}$ debe ser funcionada por personas de regular capacidad $\mathrm{p}^{\mathrm{a}}$ no berse en el hinevitable caso de errar a cada paso [...]"59. Al barajar los nombres de posibles candidatos no pesaban tanto sus capacidades o comprensión de las leyes como su conocimiento de los asuntos del distrito, de la población que lo integraba y el respeto que le guardaban sus vecinos. Se esperaba que en su accionar se rigieran por las costumbres locales y, ante cualquier duda, consultasen a las autoridades superiores o bien recurriese al consejo de una persona de su confianza más avezada en esos temas $^{60}$. El principal motivo de ello radicaba en la falta de reglamentos que guiaran su accionar. Así, para el desempeño de las tareas fiscales, los comisarios se guiaron en parte por un saber práctico y en parte por su intuición.

El desconocimiento de cómo debían cobrarse los impuestos generó conflictos y suscitó demoras a la hora de recaudar en el mundo rural. El 11 de junio de 1853, el juez de paz de Rosario, Marcelino Bayo, teniendo la orden de formar un padrón general de todos los individuos del departamento, escribía al Ministro de Gobierno, Manuel Leiva, para informarle que no logró cumplir con este cometido debido a que: "la ignorancia de los comisarios de la campaña no les permite poderlo hacer con la exactitud precisa [... $]^{\prime 61}$. Las dificultades que enfrentaban los comisarios se vislumbran en los comentarios que añadían a los listados de contribuyentes. Afirmaban que, pese a sus intenciones de cumplir con lo ordenado, ignoraban por completo de qué forma debían elaborarse los mismos o qué era preciso relevar ${ }^{62}$. En más de una oportunidad se enviaron circulares detallando la manera correcta de formar las

57 Se trataba de un cargo rentado. El recaudador de rentas del departamento Rosario debía percibir mensualmente 100 \$F, mientras que los recaudadores de La Capital y San Gerónimo recibirían 80 \$F y el de San José apenas 70 \$F. Ibídem. Mientras que el receptor de Hacienda de Rosario cobraba 80\$F mensuales y el de San Gerónimo 50\$F. Presupuesto de Santa Fe 1867. Ibídem, t. 6: 232-247.

58 Ibídem, t. 5: 162.

59 Comisarios de distrito. Arroyo del medio, 21-II-1858. AHPJM, Jefatura Política, t. 1858 B, n 23, S/f.

60 Borradores. Rosario, 29-V-1855. AHPJM, Jefatura política, t. 1855 A, nº 3, S/f. Casos similares han sido analizados por J. C. Garavaglia (2009) y D. Barriera (2009).

${ }_{61}$ Notas de los jueces de paz de esta provincia. Rosario, 11-VI-1853. AGPSF, Gobierno, t. 12, leg. 9, fs. 676.

${ }_{62}$ Comisarios de distrito. Arroyo Seco, 2-VI-1856. AHPJM, Jefatura Política, T. 1856 B, nº 9, S/f. 
planillas, pero con poco éxito obligando a los receptores a emprender la titánica tarea de homogenizarlas para ajustarlas a los requerimientos estipulados.

La falta de un reglamento claro sobre las obligaciones que tenían las autoridades de campaña en relación a la hacienda provincial fomentó su "desobediencia" a la hora de colaborar con los receptores de Hacienda. Los reglamentos impositivos fijaban pautas sobre el modo en que debían percibirse los impuestos ni los agentes encargados de ejecutar la operación. Son numerosos los autores que han mostrado como en la conformación del Estado los procesos de construcción y la aplicación de las leyes eran momentos de disputa social y no de imposición del poder estatal ${ }^{63}$. En este sentido, el ordenamiento normativo de la campaña fue complejo. En numerosas oportunidades los receptores instaron a los Colectores a emitir algún decreto en el que se especificara la forma de proceder en cuanto a la recaudación y los deberes que debían asumir los comisarios como recaudadores. Se estimaba que esta sanción serviría para coaccionarlos a cumplir con las tareas sin retrasos. Sin embargo, las autoridades provinciales se negaron a apoyar la petición porque consideraban imprudente establecer una única norma que rigiera para el conjunto de la campaña. En la provincia imperaban realidades muy contrastantes y, por lo tanto, resultaba sumamente difícil imponer reglas que no contradijeran las prácticas consideradas legítimas o alterara intereses locales ${ }^{64}$. Este panorama de grandes disparidades dejaba un amplio margen de maniobra a los poderes locales, los cuales, evaluando las necesidades de su jurisdicción, debían enunciar las tareas a cumplir, según las necesidades de cada distrito. La recaudación en el mundo rural se guiaba mediante prácticas que se ajustaban a diversas circunstancias que se presentaban y donde tenía enorme peso lo consuetudinario ${ }^{65}$.

Para paliar esta situación se resolvió simplificar la percepción de los arbitrios en el ámbito rural. Se decretó que todos los impuestos (boletas de marcas, guías, certificados patentes, matrículas, etc.) quedarían reducidos al valor del papel sellado en que debían hacerse efectivos. Así, por ejemplo, por las boletas de marcas debía pagarse al costo de un papel de sello de $5^{\circ}$ clase o por las papeletas de conchavo se cobraría el valor del papel de sello de $1^{\circ}$ clase $^{66}$. La medida se hizo extensiva a otros certificados como multas. La decisión no estuvo libre de críticas, ya que muchas de estas papeletas precisaban de averiguaciones estrictamente policiales para su apercibimiento y, a pesar de que era conveniente contar con una completa cotización de los ingresos de la provincia, resultaba difícil reducir las entradas policiales a sellos de estado. Estas tenían un precio variable, de acuerdo a lo estimado por el agente interviniente en cada caso ${ }^{67}$. La confusión que muchos ramos de hacienda despertaban (permisos de caza, licencias de baile, marchamo de perros, etc.) y lo poco que reportaban al fisco acabaron por inclinar la balanza a favor de su supresión definitiva. Al mismo tiempo, se estableció que los boletos de marca y de conchavo, los certificados, las guías y las matrículas sólo se despacharían en los expendios de papel sellado. Con esta medida se buscaba que las oficinas de hacienda asumieran

\footnotetext{
Conf. en Fradkin,1997; Garavaglia,1997; Gelman, 2000; Salvatore, 1993-1994.

Gelman, 2000: 26.

Notas de la receptoría de San Gerónimo al Contador Gral. desde enero a fines de agosto de 1862. San Gerónimo, 21-III-1862. AGPSF, Contaduría, t. 110, leg. 54, S/f.

66 ROSF, 1889, t. 4: 113.

67 Informe del departamento de policía de Rosario sobre cobro de multas e impuestos que forman las entradas eventuales de policía. Rosario, 8-I-1863. AGPSF, Contaduría, t. 115, leg. 29, S/f.
} 
un control más estricto sobre la colecta ${ }^{68}$. Finalmente se prohibió a los comisarios de distritos librar sueldos o invertir el dinero recaudado, sin la respectiva orden del receptor del departamento, y se ordenó que las rentas percibidas se ingresaran de forma inmediata a las cajas departamentales. Además, se los obligó a llevar un libro en donde fueran asentados todos los movimientos de entradas y salidas. Estos libros debían ser utilizados para elaborar las cuentas que anualmente debía presentar, haciéndoselos responsables de cualquier error ${ }^{69}$.

\section{Distancias y proximidades: diferentes miradas sobre la recaudación en el mundo rural}

El mundo rural ha sido descripto por los receptores de hacienda como un espacio demasiado extenso y distante. Sin embargo, la noción de distancia no puede reducirse a lo estrictamente físico, es decir la distancia física que existía entre las oficinas de hacienda y la población de la campaña. Aparecen otras distancias que merecen ser consideradas $^{70}$. Este apartado propone un acercamiento a algunos de los puntos más álgidos de disputa entre receptores y comisarios de distrito a través del binomio distancia/proximidad. La proximidad física de los agentes, los vínculos entre la distancia física y los tiempos en el desempeño de sus tareas constituyen factores centrales en el proceso de recaudación fiscal.

\subsection{Recaudadores, vecinos y contribuyentes: la cercanía de los vínculos}

Uno de los principales puntos de discusión en torno a la recaudación de rentas recaía en la propia procedencia de los comisarios, a saber, se trataba de vecinos del lugar con extensos vínculos en el distrito. Estos fueron, en general, personas influyentes en lo local que tenían experiencia en el manejo de asuntos tanto políticos como económicos y que contaban con la confianza de sus coterráneos, lo que les brindaba amplias ventajas para moverse en el entramado social rural. Las comunidades rurales estaban constituidas por fuertes lazos de solidaridad donde la asociación de sus integrantes era vital para su subsistencia y la confianza mutua una práctica corriente. Estaban obligados, de alguna manera, a ganarse la legitimidad y el consenso de los habitantes de la campaña a los que representaban, permitiéndole al gobierno, al mismo tiempo, establecer un sistema de control más directo, pero asentado en poderes locales socialmente construidos con los cuales mantenían fuerte vinculaciones ${ }^{71}$. Tal como quedó retratado en uno de los mensajes del entonces gobernador, Rosendo Fraga: "el Gobierno ha tenido el cuidado de nombrar para esos puestos, a ciudadanos domiciliados y con intereses rurales, que no pueden menos de tener vigilancia hasta por sus propias conveniencias $[\ldots]^{\prime 72}$. Por lo cual, los comisarios fueron casi sin

\footnotetext{
ROSF, 1889, t. 5: 452.

Ibídem, t. 8: 99.

70 Darío Barriera (2012) ha postulado la existencia de cinco tipos de distancia entre jueces y población: física, material, cultural, procesal y social.

71 Las vinculaciones entre miembros de las élites urbanas y rurales de Santa Fe han sido estudiadas por Bonaudo - Sonsogni, 1992.

72 "Mensaje del Sr. Gobernador de la Provincia de Santa Fe, Don ROSENDO M. FRAGA, a la H. Asamblea Legislativa, Año 1860". Comisión redactora de la Historia de las instituciones de la provincia de Santa Fe, 1972: 99.
} 
excepción hacendados propietarios de ganados (vacunos, yeguarizo y lanar) algunos de los cuales se dedicaban a su vez al comercio. Aunque no siempre se trataba de los vecinos más ricos del lugar, tenían intereses personales y concretos en el distrito ${ }^{73}$.

La residencia en estos distritos garantizaba un conocimiento más acabado de vecinos y moradores, y garantizaba contar con el respeto de la comunidad. Sin embargo, hallarse inmerso en las redes de relaciones locales donde primaba la cercanía de los lazos (familiares, comerciales, de amistad o de compadrazgo), les impedía un cierto distanciamiento simbólico y podía en tela de juicio los supuestos de imparcialidad y desinterés que debían tener como representante del gobierno provincial ${ }^{74}$. La idea de una cierta familiaridad entre autoridad y población ha permitido, y permite, a quien pudiera sentirse afectado manifestar dudas sobre los efectos de aquella proximidad. Tal vez en donde mejor se reflejó estas dificultades fue en torno al cobro de la contribución directa ${ }^{75}$. Se trataba de un impuesto que tuvo una especial repercusión en el mundo rural. Pese a que se nombraron Comisiones encargadas de la regulación de los capitales y el cobro de las cuotas a cada contribuyente, como se ha señalado ya, en la campaña la tarea recayó sobre los comisario de distrito ya que se estimaba que conocerían con más detalle el área y lograrían, de esta forma, evitar cualquier ocultación ${ }^{76}$. Esta decisión fue vista por muchos legisladores un arma de doble filo, pues consideraban que confiándoles la confección de planillas se corría el riesgo de que los vínculos con sus vecinos o sus propios intereses pesaran más que sus obligaciones para con el erario. No faltaron oportunidades en que algunos Comisionados manifestaran que el contenido de los registros de contribuyentes era cuanto menos "dudoso"77. En las circulares sobre la recaudación de este impuesto se recuerda a las autoridades de campaña, en numerosas ocasiones, la importancia de cumplir sin miramientos con estas tareas ${ }^{78}$.

\subsection{La distancia como un obstáculo a sortear}

La espacialidad es un factor clave a la hora de pensar la colecta impositiva y la trama que se desplegada en torno a este proceso. La distancia que separaba las oficinas de hacienda de los distintos puntos de la campaña constituía un obstáculo difícil de sortear. Como se ha señalado ya, los empleados de hacienda tropezaban con un sinnúmero de inconvenientes para dejar sus oficinas. Para efectuar la recaudación en el mundo rural, el receptor dependía de los comisarios de distrito. Sin embargo, estos se hallaban inmersas en un escenario que era definido como demasiado extenso y, por lo tanto, complejo de controlar, condicionando así sus tareas.

73 Tal como muestra el trabajo de Garavaglia (1997) para el caso de Buenos Aires. Para Entre Ríos, Roberto Schmit señala que hacendados y comandantes militares "la mayor parte de las veces eran las mismas personas". Schmit, 2008. Gisela Sedeillán (2004) ha abordado la policía de Tandil para las décadas finales del siglo XIX y ha revelado cómo hasta la creación de la Policía de la Provincia de Buenos Aires, la figura del comisario recaía en un vecino reconocido de la comunidad. Un perfil sobre autoridades de campaña para el caso de Tucumán ha sido abordado por Parolo (2011). Sobre los comisarios de distrito en Santa Fe: De los Ríos - Piazzi, 2013.

74 Véase: Barriera, 2013; Molina, 2014.

75 Sobre las dificultades en la recaudación de la contribución directa ver: Santilli, 2010; Gelman - Santilli, 2006; Irigoin, 2006.

76 ROSF, 1889, t. 3: 30. El término ocultación remite a la acción de encubrir bienes con el fin de no pagar tributos. Pro Ruiz, 1995: 90.

77 Receptoría de Hacienda. Rosario, 29-VII-1858. AHPJM, Jefatura Política, t. 1858 B, n 21, S/f.

78 Receptoría de Hacienda. Rosario, 23-X-1857. AHPJM, Jefatura Política, t. 1857 C, n 24, S/f. 
La imprecisión de los límites entre los distritos afectaba no sólo el desempeño de las operaciones políticas y en el ejercicio de la justicia, sino que también interfería en la recaudación. Cuando el comisario del distrito de Desmochados en el departamento de San Gerónimo, quien además ejercía el cargo de recaudador de rentas, Alejandro Correa, remitió su percepción a la Caja de Rosario despertó una gran polémica: el receptor de Coronda reclamó ante el Colector general que ese dinero debía ingresarse como entradas en su departamento, una oficina que se encontraba muy limitada de recursos. Consideró tan grave el accionar del comisario que solicitó que fuera cesado del cargo. Este se excusó ante el Colector afirmando que no tenía claro donde remitir la colecta y que por encontrarse cerca de Rosario giró el dinero en aquella receptoría ${ }^{79}$. Una situación idéntica se repitió una década más tarde, el receptor envió a un sargento de la partida de plaza a efectuar el cobro de una patente de pulpería a más de treinta leguas de distancia del pueblo y encontró que el tenedor de la licencia afirmaba haberla estado pagando al jefe político de Rosario. Una vez más el receptor escribió al Colector relatando: "en virtud que no consta ninguna Partida en los Cuadernos que me ha entregado, és prueba que nunca á habonado en esta Caja el señ. Montenegro los Dros fiscales, ni comprendo como puede el jefe Político del Rosario, conseccionar licencias para Distintos Departamentos [... $]^{\prime 80}$.

Para acortar la distancia se procedió a la subdivisión de los distritos nombrando nuevos comisarios. En la práctica, la medida mostró no ser siempre efectiva. Muchos nombramientos recayeron sobre personas que residían en puntos extremos de la jurisdicción. En esta oportunidad fueron los propios vecinos los que aportaron una solución sencilla: nombrar autoridades que residieran en el centro de cada distrito. Los vecinos de Desmochados proponían a Agustín Jiménez como comisario solo por vivir en el centro del distrito ${ }^{81}$. De igual manera en el de Saladillo de la Orqueta presentaron un petitorio al Gobernador en lo que afirmaban que meses antes se había nombrado comisario a Gregorio Paz, quien debido a que vivía en el extremo sur no podía satisfacer las exigencia de su empleo, por lo que recomendaban a Pantaleón Rodríguez "porque reúne todas las condiciones de la ley, y esta domiciliado en el centro del susodicho distrito [... $]^{\$ 82}$.

Conseguir que los vecinos rurales cumplieran con sus obligaciones fiscales fue una tarea compleja, no sólo porque estos no habían internalizado el pago de los impuestos como parte de sus deberes como ciudadanos ${ }^{83}$, tampoco era factible para la población rural trasladarse hasta la receptoría departamental para cumplir con estos compromisos. Los vecinos de San José, por ejemplo, debía galopar siete u ocho leguas y pasar cuatro arroyos para llegar a esa Capital y poder conseguir allí las licencias para llevar sus frutos al puerto del Paraná ${ }^{84}$. No se trataba sólo de un recorrido métrico, se sumaban todo un conjunto de factores que incidían en los traslados: los medios de transportes, los peligros naturales, cuestiones ambientales, etc. ${ }^{85}$. Así,

79 Notas del receptor de Coronda Don. Felipe Fernández al contador Gral. D. José A. Lassaga. San Gerónimo, 8-I-1852. AGPSF, Contaduría, t. 90, leg. 13, S/f.

80 Notas de la receptoría de San Gerónimo al Contador Gral. desde enero a fines de agosto de 1862. San Gerónimo, 30-VII-1862. AGPSF, Contaduría, T. 110, leg. 54, S/f.

${ }_{81}$ Notas de los jueces de paz de esta provincia. Desmochado, 21-III-1861. AGPSF, Gobierno, t. 21, leg. 12 , fs. 865.

82 Solicitudes varias. Rosario, 12-III-1854. AGPSF, Gobierno, t. 25, leg. 16, fs. 694.

83 La bibliografía sobre esta problemática es abundante remitimos a: Vallejo Pousada, 1996; Pro Ruiz, 1995. Sobre la construcción de los ciudadanos como contribuyentes: Pan-Montojo, 2007; Botana, 2006; Parolo - Herrera, 2011.

${ }_{84}$ Notas de los jueces de paz de esta provincia. San José, 18-I-1853. AGPSF, Gobierno, t. 18, leg. 11, fs. 1415.

85 Barriera, 2013. 
la remisión de patentes y guías de campaña a algunos distritos rurales alejados más de treinta leguas se vio interrumpida debido a motivos políticos y a una gran seca que provocó que el comisario no contara con caballos para realizar sus tareas ${ }^{86}$. Los vecinos, por su parte, preferían arriesgarse al pago de multas antes que sortear todas las dificultades que suponía el cumplimiento de la legislación fiscal. Para remendar esta situación se solicitó a todos aquellos tenedores de patentes, que no pudiesen o quisiesen comparecer en las oficinas de hacienda que, al menos, se comprometiesen a nombrar un fiador en la ciudad o el pueblo que se encargara de hacer efectivos, en su nombre, los abonos correspondientes ${ }^{87}$.

La distancia fue contemplada en las leyes fiscales y traducidas en términos temporales: se fijaron plazos diferentes a los habitantes del mundo rural para el cumplimiento de las cargas fiscales considerando que las formas de recaudar ciertos impuestos, las demoras en las remisiones de planillas y los retrasos en informar de sus obligaciones frenaban la percepción de los impuestos ${ }^{88}$. Las autoridades provinciales fueron especialmente indulgentes con los vecinos de la campaña porque conocían que los comisarios "tenían demasiadas ocupaciones para darle prioridad a las fiscales" y estos no siempre eran notificados en los plazos correspondientes ${ }^{89}$. El comisario del distrito de Arroyo de Medio centro, Víctor Basabúa, el 18 de mayo de 1860, le escribía al Jefe político señalando:

Ha venido algunos vecinos diciéndome que se les cobra doble por las voletas de marcas, por no haberlos sacado á su tiempo, á lo que yo digo que no han tenido culpa ninguna, pues en este mes es cuando se les ha hecho presente dicha órden que sin embargo de haberse ordenado desde Enero, ha habido motivos por los que hasta la fecha no se ha impartido esta orden, y son el haber estado este distrito poco menos que acéfalo un tiempo que vino ese orden y otras muchas, que cuando yo las recibí del que fue nombrado comisario y no aceptó, estaban muy atrasadas es decir vencida el tiempo prefijado en que debian ser cumplida $[\ldots]^{90}$.

Argumentos como el que sigue se repitieron a lo largo de todo el período suavizando la aplicación de medidas por evasión de impuestos:

[...] comprendida las dificultades que diariamente se suscitan al exigirse el pago de las multas a los contribuyentes quienes manifiestan no haber recibido las cédulas por las cuales se les cobra dicho impuesto, y siendo de todo punto imposible verificar esto en atencion á los informalidades observadas en el reparto de ellas; es de parecer que, desde la fecha no se exija a las contribuyentes el importe de las multas en que pueden haber incurrido, obligándoseles si, a que obren en tesorería las cantidades que adeudan $[\ldots]^{91}$.

86 Notas de la receptoría de San Gerónimo al Contador Gral. dirigidas durante el último cuatrimestre de 1862. San Gerónimo, 27-IX-1862. AGPSF, Contaduría, t. 110, leg. 55, S/f.

87 Notas de la receptoría de San Gerónimo al contador Gral. desde enero a fines de agosto de 1862. San Gerónimo, 12-V-1862. AGPSF. Contaduría, t. 110, leg. 54, S/f.

88 Los vínculos entre distancia física y tiempo han sido retomados por investigaciones actuales desde la vertiente de la Historia social de la Justicia como vector de análisis en ejecución de los procesos judiciales. Piazzi, 2017.

89 Notas del juez de paz de San José al Contador general durante el año 1863. Santa Fe, 10-VIII-1863. AGPSF, Contaduría, t. 112, leg. 79, S/f.

90 Comisarios de distrito. Arroyo del medio centro, 18-V-1860. AHPJM, Jefatura Política, t. 1860 A, n 4, S/f.

91 Oficinas de Hacienda. Rosario, 20-X-1871. AGPSF, Gobierno, t. 36, leg. 6, S/f. 
Por lo cual, se otorgó a los contribuyentes un margen de tres días, en la ciudad, y diez, en la campaña, para regularizar su situación. Finalmente, si pasado ese tiempo alguno no pagaba, se le embargarían los bienes ${ }^{92}$.

\subsection{Una comunicación mediada}

La comunicación entre los receptores de hacienda y los comisarios de campaña estaba mediada por la intervención de las máximas autoridades departamentales -el jefe político, en el de Rosario, y los jueces de paz, en los restantes- quienes les informaban de las tareas a cumplir, los supervisaban en el desempeño de sus responsabilidades de hacienda, les remitían las leyes y las disposiciones fiscales. Al igual que los comisarios, la multitud de tareas que acumulaban los jueces de paz y el jefe político provocó continuas demoras en la entrega de guías y papeletas retrasando así la recaudación de impuestos.

Para que la recaudación fuera efectiva se requería que el engranaje de vínculos funcionara de forma aceitada y que las autoridades mantuvieran entre sí relaciones cordiales. De no cumplirse estas condiciones la tarea resultaría imposible. Observemos un ejemplo: el 15 de marzo de 1862 fue designado receptor de hacienda del departamento de San Gerónimo, José María Torres, un comerciante del pueblo. Desde hacía un tiempo estas funciones eran desempeñabas por el juez de paz Anselmo Maciel - un hacendado del distrito de Barrancas que contaba con cierta trayectoria en este puesto. El nombramiento de Torres tenía por objetivo aliviar las tareas del juez debido a que acumulación de labores entorpecían el funcionamiento de ambas oficinas, receptoría y juzgado. Sin embargo, lejos de ser un "alivio" las desavenencias entre ambos desató una seria disputa que afectó la recaudación fiscal del departamento $\mathrm{y}$, por ende, los intereses provinciales. A través de una copiosa serie de cartas que el receptor envía al Colector General se deja entrever los principales focos de conflictos donde el receptor acusaba al juez de paz de obstaculizar su tarea negándose al envío de vigilantes para la realización de servicios fuera de la oficina. El enfrentamiento alcanzó tal nivel que el receptor declaró que le resultaba imposible ir personalmente al juzgado, teniendo que pagarle a otra persona para ello. Uno de los principales puntos de discusión giraba sobre la recaudación en el mundo rural. Según el receptor, Maciel se niega a remitir las comunicaciones de hacienda a los comisarios perjudicando con su conducta al erario provincial ${ }^{93}$.

Tal vez la denuncia más grave que lanzó sobre el juez de paz fue la imputación de que buscaba mantener endeudada a la receptoría exonerando de pagar impuestos a los deudores de la hacienda. El receptor afirmaba que los contribuyentes se negaban a pagar porque aseguraban que el juez los había exceptuado, lo que constituía una prerrogativa que era exclusiva del gobernador. Para el receptor, esta política de exoneración no era azarosa, sino que iba dirigida a beneficiar a ciertos "amigos", haciendo uso de su poder discrecional con una tendencia clara al favoritismo. Estas prácticas no sólo defraudaban al tesoro provincial, sino que mermaban la propia autoridad del receptor quien temía que: "llegará el caso en que aparezcan los estafa-

\footnotetext{
92 Comisión de regulación de la contribución directa de Santa Fe da cuenta del ingreso de este rubro. Santa Fe, 20-XII-1860. AGPSF, Escribanía de gobierno, t. 7, exp. 45, fs. 168.

93 De los Ríos, 2017 b.
} 
dores que no falta y á nada obedecerán mi receptoría"94. En un contexto provincial donde la mayor parte de los esfuerzos en lo tocante a la fiscalidad estaban enfocados en incrementar las rentas - que no alcanzaban a cubrir los gastos que pesaban sobre la administración-, un reclamo de esta naturaleza causó un fuerte impacto entre las autoridades provinciales ${ }^{95}$.

Ante las constantes acusaciones dirigidas por el receptor, el colector de la provincia, León Mujica, le solicitó que hiciera todos los esfuerzos a su alcance para entenderse con el juez de paz, a quien debía persuadir de la importancia que tenía el cumplimiento de sus funciones y de la necesidad de prestar su colaboración con la receptoría. A tal punto llegaron las desavenencias que el Ministro de gobierno se vio forzado a intervenir para recordarles a ambos que:

los jueces de paz los representantes del gobierno en los Departamentos en la parte política y administrativa asi como son tambien ajentes y miembros del poder judicial en los términos del Reglamento vigente en la materia, hay sin embargo un ramo que es el de Hacienda del que solo el Receptor está encargado; pero que como este funcionario no dispone de los necesarios elementos para asegurar la exacta percepcion de las rentas, el juez de paz debe presentarle manifiesto para auxiliarlo y ayudarlo en el desempeño de regularizar la hacienda siendo que serian estériles todos los esfuerzos del gobierno en este sentido aun cuando se an asegurados por la acción del Receptor que no puede ser eficaz sin el concurro del juzgado de paz ${ }^{96}$.

\section{Conclusión}

En esta investigación se proponía un acercamiento a las formas en que se cobraban los impuestos en el mundo rural santafesino en el siglo XIX como un punto de partida hacia una conceptualización más compleja sobre el proceso de conformación de la administración estatal. Los discursos de gobernadores, jefes políticos y legisladores, por un lado, y los ideales bosquejados en las reglamentaciones fiscales, por otro, que remarcaban la creación de nuevas oficinas y el incremento del número de oficiales como aspectos claves del proceso chocaron pronto con la realidad de la fiscalidad provincial. Las dificultades de dotar a dichas oficinas con los recursos necesarios para su funcionamiento -auxiliares, servicios de postas y caballos, mobiliario, etc.y de proporcionar a los empleados sueldos acorde a las exigencias que conllevaba el trabajo constituye la otra cara de la moneda. En este sentido, una mirada a ras de suelo nos muestra toda una esfera de acción no visible desde el diseño ideal de la administración centralizada y jerarquizada de las oficinas de hacienda. Se trata de una "burocracia a la sombra" que cumplía con un conjunto de tareas fiscales: cobrar los impuestos, elaborar las planillas de ingresos y egresos, informar de los plazos estipulados para el pago de los tributos, confeccionar los registros de contribuyentes,

94 Notas y cartas del Receptor y juez de paz de Coronda al Contador general durante el $1^{\circ}$ semestre de 1863 . San Gerónimo, 26-I-1863. AGPSF, Contaduría, t. 113, leg. 29, S/f.

95 Una problemática similar ha sido abordada por Alvero (2006) para el caso de la provincia de Catamarca.

96 Anselmo Maciel, juez de paz de San Gerónimo reprobado por decreto gubernativo por su conducta que observa para con el receptor de hacienda D. José María Torres. Santa Fe, 21-II-1863. AGPSF, Contaduría, t. 112, leg. 48, $\mathrm{S} / \mathrm{f}$. 
etc. En el mundo rural santafesino, los comisarios de distrito desempeñaron estas funciones fiscales. Se trataba de vecinos del lugar, personas influyentes en lo local que contaban con con extensos vínculos en el distrito. Estas condiciones les brindaban amplias ventajas para moverse en el entramado social de la campaña.

Una segunda cuestión a considerar era: ¿Cuánto pesaban las proximidades y las distancias de las autoridades de campaña a la hora de recaudar los impuestos? Las investigaciones actuales han señalado ya que la menor o mayor distancia existente entre gobernantes y gobernados, o entre gobierno y población no resulta un componente fijo de la configuración, es decir que las autoridades se encuentren más cercanas o más distantes respecto de la población sobre la que gobiernan no es necesariamente negativo ni positivo, requiere ser valorado en cada situación ${ }^{97}$. Las distancias o proximidades son relativas, según quien las esgrimes y las convierten en una finalidad para sus intereses. En la designación de los comisarios como recaudadores de impuestos se valoraba más su "proximidad", su inmediatez y conocimiento respecto a la comunidad sobre la que debían actuar, y sus vínculos con la población y el territorio. Así, por ejemplo, el nombramiento de recaudadores de rentas fiscales fue un vano intento de centralizar la colecta en manos de empleados que dependían directamente del departamento de Hacienda. Los inconvenientes que hallaron los recaudadores a la hora de cumplir con sus tareas, expresados en su continua solicitud de auxilio a los comisarios, demostraron que si se pretendí conseguir que los contribuyentes acataran las órdenes emanadas desde el gobierno central se requería de la presencia de autoridades que fueran "conocidas y respetadas" entre la población local.

El estudio en profundidad de los agentes que intervenían en la recaudación y el entramado de relaciones en el que se movían -no sólo a nivel local sino también en diferentes esferas de la administración provincial- muestran cómo operaban los procesos fiscales en la realidad local y permite repensar las dinámicas de poder que se tejían al interior del estado. Una mirada renovada sobre la administración de hacienda constituye un terreno fértil para determinar especificidades y realizar estudios comparativos sobre los comportamientos institucionales y su interacción social alejados de las visiones estatalistas.

\section{Referencias bibliográficas}

Argentina. Primer Censo Nacional de la República Argentina [1869]. Buenos Aires: Imprenta El Porvenir, 1872.

Alonso, Fabián - Barral, María Elena - Fradkin, Raúl - Perri, Gladys. "Los vagos de la campaña bonaerense. La construcción histórica de una figura delictiva (1730-1830)". Prohistoria, $\mathrm{n}^{\circ} 5$ (2001), 99- 128.

Alonso García, David. "Poder financiero y arrendadores de rentas reales en Castilla a principios de la Edad Moderna". Cuadernos de Historia Moderna, vol. 31 (2006), 117-138. Disponible en http://revistas.ucm.es/index.php/CHMO/article/view/CHMO0606110117A

Álvarez, Juan. “Guerra económica entre la Confederación y Buenos Aires (1852-1861)”. En Historia de la Nación Argentina, vol. VIII: La Confederación y Buenos Aires hasta la organización definitiva de la nación en 1862, editado por Levene, Ricardo. Buenos Aires: Librería editorial El Ateneo, 1947 [2º edición], 135-162.

$97 \quad$ Barriera, 2013. 
Alvero, Luis Alejandro. "Fiscalidad y poder político en el Noroeste Argentino. El papel de los recaudadores de rentas en Catamarca 1890-1910". Ponencia en las VI Jornadas Nacionales Espacio, Memoria e Identidad, UNR, 2006.

Amaral, Samuel. "Public expediture Financing in the colonial treasury: an análisis of the Real Caja de Buenos Aires accounts, 1789-1791". Hispanic American Historical Review, nº 64, vol. 2 (1984), 287-295.

Barral, María E. - Fradkin, Raúl - Perri, Gladys. “QQuiénes son los perjudiciales? Concepciones jurídicas, producción normativa y práctica judicial en la campaña bonaerense (1780-1830)". En El poder y la vara: estudios sobre la justicia y la construcción del Estado en el Buenos Aires rural: 170-1830, editado por Fradkin, Raúl. Buenos Aires: Prometeo Libros, 2007, 129-153.

Barriera, Darío. "Lenguajes y saberes judiciales en los legos en el Río de la Plata (siglos XVI y XIX)". En Historia de la cuestión criminal en la Argentina, editado por Sozzo, Máximo. Buenos Aires: Editores del Puerto, 2009, 83-99.

— "Justicia de proximidad: pasado y presente, entre la historia y el derecho". Pol-His. Boletín Bibliográfico electrónico del Programa Buenos Aires de Historia Política, $\mathrm{n}^{\mathrm{o}} 10$ (2012), 50-57. Disponible en http://www.historiapolitica.com/datos/boletin/Polhis10 BARRIERA.pdf

— "Entre el retrato jurídico y la experiencia en el territorio. Una reflexión sobre la función distancia a partir de las normas de los Habsburgo sobre las sociabilidades locales de los oidores americanos". Caravelle. Cahiers du monde hispanique et luso-brésilien, $\mathrm{n}^{\mathrm{o}} 101$ (2013), 133-154. Disponible en http://journals.openedition.org/caravelle/608

Bonaudo, Marta (comp.). Nueva Historia de Santa Fe: la organización productiva y política del territorio provincia (1853-1912), tomo 6. Rosario: La Capital, 2006.

Bonaudo, Marta - Sonzogni, Élida. "Redes parentales y facciones en la política santafesina, 1850-1900". Siglo XIX. Revista de Historia, n 11 (1992), 74-110.

— "El problema de la fiscalidad en la reorganización provincial en la etapa posrosista. Santa Fe (1853-1880)". Prohistoria, nº 1 (1997), 73-87.

— "Cuando disciplinar fue ocupar (Santa Fe, 1850-90)". Mundo Agrario. Revista de estudios rurales, vol. 1, $\mathrm{n}^{\mathrm{o}} 1$ (2000). Disponible en https://www.redalyc.org/articulo. oa? id $=84510103$

Botana, Natalio. "La ciudadanía fiscal. Aspectos políticos e históricos". En La brecha entre América latina y los Estados Unidos. Determinantes políticos e institucionales del desarrollo económico, editado por Fukuyama, Francis. Buenos Aires: Fondo de Cultura Económica, 2006, 261-322.

Bose, Walter. "Las postas en las provincias de Santa Fe, Entre Ríos, Corrientes y Misiones (1772-1820)". Trabajos y comunicaciones, no 20 (1970), 87-130.

Bosher, J. F. French Finances 1770-1795: from Business to Bureaucracy. Cambridge: Cambridge University Press, 1970.

Bulmer-Thomas, Víctor. The Economic History of Latin America since Independence. Cambridge: Cambridge University Press, 2003.

Burgin, Miron. Aspectos económicos del federalismo argentino. Buenos Aires: Librería Hachette, 1960.

Carrasco, Gabriel. Descripción geográfica y estadística de la Provincia de Santa Fe. Rosario: Imprenta de Carrasco, 1884.

Chiaramonte, José Carlos - Cussianovich, Guillermo - Tedeschi, Sonia. "Finanzas públicas y política interprovincial: Santa Fe y su dependencia de Buenos Aires en tiempos de Estanislao López". Boletín del Instituto de Historia Argentina y Americana "Dr. Emi- 
lio Ravignani”, no 8 (1993), 77-116. Disponible en https://dialnet.unirioja.es/servlet/ articulo? codigo $=5165200$

Coastworth, John. Los orígenes de atraso. México: Alianza, 1990.

Comisión redactora de la Historia de las instituciones de la provincia de Santa Fe. Historia de las instituciones de la provincia de Santa Fe. Santa Fe: Imprenta Oficial, 1972.

De la Fuente, Diego - Carrasco, Gabriel. Segundo censo de la República Argentina mayo 10 de 1895, tomo II. Población: Taller Tipográfico de la Penitenciaría Nacional, 1898.

De los Ríos, Evangelina. Gobernar es cobrar. Política fiscal, recaudación impositiva y cultura tributaria. Santa Fe, (Argentina, 1855-1872). Rosario: Prohistoria Ediciones, 2017a.

— "El Receptor y el juez de paz: una mirada sobre la gestión cotidiana de los impuestos. San Gerónimo, Santa Fe (segunda mitad del siglo XIX)". En Estudios en Historia Moderna desde una visión Atlántica. Libro Homenaje a la trayectoria de la profesora María Inés Carzolio, editado por Vincent, Bernard - Lagunas, Cecilia - Reitano, Emir - Sanmartín Barros, Israel - Tarragó, Griselda - Polo Sánchez, Julio - González Mezquita, María Luz Moriconi, Miriam - Pereyra, Osvaldo Víctor. La Plata: FaHCE - UNLP, 2017b, 470-492.

De los Ríos, Evangelina - Piazzi, Carolina. "Comisarios de campaña en el departamento Rosario: entre ocupaciones públicas e intereses privados: (1850-1865)". En Las fuerzas de guerra en la construcción del Estado: América Latina, siglo XIX, editado por Garavaglia, Juan Carlos - Pro Ruiz, Juan - Zimmermann, Eduardo. Rosario: Prohistoria ediciones, 2013, 379-412.

Djenderjdjian, Julio - Martirén, Juan Luis - Berzotti, Sílcora. Expansión agrícola y colonización en la segunda mitad del siglo XIX, tomo 6, vol. 2: Historia del capitalismo agrario pampeano. Buenos Aires: Editorial Teseo, 2010.

Ensinck, Oscar. "Recursos fiscales en la provincia de Santa Fe. Derechos de aduanas y presupuestos (siglo XIX)". Revista de la Junta Provincial de Estudios Históricos de Santa $F e, n^{\circ} 56$ (1953), 45-49.

Etchechury Barrera, Mario. "Taxation without Bureaucracy? Republican Governments and the Old fiscal regime in the Estado oriental del Uruguay: An approach through Tax Farming, 1828-1852". En Latin American Bureaucracy and State Building Process (17801860), editado por Garavaglia, Juan Carlos - Pro Ruiz, Juan. Cambridge: Cambridge College, 2013, 371-401.

Fradkin, Raúl. "Entre la ley y la práctica: la costumbre en la campaña bonaerense de la primera mitad del siglo XIX". Anuario IEHS, no 12 (1997), 141-156.

Fradkin, Raúl - Ratto, Silvia. "Territorios en disputa. Liderazgos locales en la frontera entre Buenos Aires y Santa Fe (1815-1820)". En Desafios al orden. Política y sociedades rurales durante la Revolución de Independencia, editado por Fradkin, Raúl - Gelman, Jorge. Rosario: Prohistoria ediciones, 2008, 37-60.

Frid, Carina. "Desigualdad y distribución de la riqueza en escenarios de crecimiento económico: Santa Fe, 1850-1870”. En El mapa de la desigualdad en la Argentina del siglo XIX, editado por Gelman, Jorge. Rosario: Prohistoria, 2011, 95-138.

— "Producción agraria y crecimiento económico en el sur de Santa Fe (1840-1860)". En De la expansión agraria al desarrollo industrial: la economía de Santa Fe entre 1850 y 1970, editado por Frid, Carina - Lanciotti, Norma. Rosario: Prohistoria ediciones, 2013, 17-48.

Gallo, Ezequiel. "Santa Fe en la segunda mitad del siglo XIX. Transformaciones en su estructura regional". Anuario del Instituto de Investigaciones Históricas de la Universidad Nacional del Litoral, ${ }^{\circ} 7$ (1965), 127-161.

_ “Ocupación de tierra y colonización agrícola en Santa Fe (1870-1895)". En Tierras nuevas. Expansión territorial y ocupación del suelo en América (siglos XVI-XIX), editado 
por Jara, Álvaro - Florescano, Enrique - Halperín Donghi, Tulio - Gallo, Ezequiel - Carrera Damas, Germán - Mallafe, Rolando. México: Colegio de México, 1969, 92-104.

- La Pampa Gringa. La colonización agrícola en Santa Fe (1870-1895) [1983]. Buenos Aires: Edhasa, 2004.

Garavaglia, Juan Carlos. "Paz, orden y trabajo en la campaña: la justicia rural y los juzgados de paz en Buenos Aires, 1830-1852". Desarrollo Económico, vol. 37, no 146 (1997), 241-262

— "La cruz, la vara, la espada. Las relaciones de poder en el pueblo de Areco". En Justicias y fronteras. Estudios sobre historia de la justicia en el Río de la Plata. Siglos XVI-XIX, editado por Barriera, Darío. Murcia: Servicio de Publicaciones Red Columnaria-Universidad de Murcia, 2009, 89-118.

- "Servir al Estado, servir al poder: la burocracia en el proceso de construcción estatal en América Latina". Almanack. Guarulhos, no 3 (2012), 5-26. Disponible en http://www. scielo.br/scielo.php?pid=S2236-46332012000100005\&script=sci_abstract\&tlng=es

Gelman, Jorge. "Crisis y reconstrucción del orden en la campaña de Buenos Aires. Estado y sociedad en la primera mitad del siglo XIX". Boletín de Historia Argentina y Americana “Dr. Emilio Ravignani”, no 21 (2000), 7-31.

— "Los avatares de la transición fiscal y el ciclo económico. Algunos comentarios". Illes $i$ Imperis, $\mathrm{n}^{\mathrm{o}} 13$ (2010), 203-213.

Gelman, Jorge - Santilli, Daniel. "Los límites del proyecto modernizador. La Contribución Directa en Buenos Aires durante la primera mitad del siglo XIX". Ponencia en XIV International Economic Congress, Helsinki, 2006.

Halperín Donghi, Tulio. Guerra y finanzas en los orígenes del estado argentino (1791-1850) [1985]. Buenos Aires: Prometeo Libros, 2006.

Hespanha, António. La gracia del derecho. Economía de la cultura en la Edad Moderna. Madrid: Centro de Estudios Constitucionales, 1994.

Iriondo, Urbano. Apuntes para la historia de la provincia de Santa Fe. Santa Fe: Junta Provincial de Estudios Históricos, 1968.

Irigoin, María Alejandra. "Ilusoria equidad: la reforma de las contribuciones directas en Buenos Aires, 1850". En De riqueza e inequidad. El problema de las contribuciones directas en América Latina, siglo XIX, editado por Jauregui, Luis. México: Instituto Mora, 2006, 47-77.

Klein, Herbert S. “Las finanzas reales en el Río de la Plata, 1630-1809”. En Nueva Historia de la Nación Argentina, editado por Academia Nacional de Historia. Buenos Aires: Planeta, 1999, 13-30.

Klein, Herbert S. - Tepaske, John. The Royal Treasuries of the Spanish Empire in America, vol. 1 (Perú), vol. 2 (Bolivia), vol. 3 (Chile y Río de la Plata). North Carolina: Duke University Press, 1982.

Lynch, John. Administración colonial española, 1782-1810: el sistema de intendencia en el Virreinato del Río de la Plata. Buenos Aires: EUDEBA, 1967.

Mariluz Urquijo, José M. "El Tribunal Mayor y Audiencia Real de cuentas de Buenos Aires". Revista del instituto de Historia del Derecho, vol. 3 (1951), 116-118.

Miatello, Hugo. Investigación agrícola sobre la provincia de Santa Fe. Anales del Ministerio de Agricultura. Buenos Aires: Compañía Sud- americana de Billetes de Banco, 1904.

Molina, Eugenia. "Justicia de proximidad y gobierno político-militar en la frontera. Equipamiento institucional del Valle de Uco (Mendoza) durante el proceso revolucionario (1810-1820)". Mundo Agrario, vol. 15, nº 30 (2014). Disponible en: http://www.mundoagrario.unlp.edu.ar/article/view/MAv15n30a07/6458 
Pan-Montojo, Juan. “Ciudadanos y contribuyentes”. En De súbditos a ciudadanos: una historia de la ciudadanía de España, editado por Pérez Ledesma, Manuel. Madrid: Centro de Estudios Políticos Constitucionales, 2007, 483-520.

Parolo, María Paula. "El perfil social de las autoridades locales en la campaña tucumana a mediados del siglo XIX". En Modos de hacer justicia. Agentes, normas y prácticas. Buenos Aires, Tucumán y Santa Fe durante el siglo XIX, editado por Piazzi, Carolina. Rosario: Prohistoria, 2011, 113-127.

Parolo, María Paula - Herrera, Claudia E. "Las dos caras de la fiscalidad: Estado y contribuyentes. Tucumán, 1853-1870”. Boletín del Instituto de Historia Argentina y Americana “Dr. Emilio Ravignani”, no 34 (2011), 47-76.

Piazzi, Carolina. “Administración y materialidad: una etnografía del Juzgado del Crimen del Rosario (Argentina, segunda mitad del siglo XIX)". Historia Crítica, n 63 (2017), 53-74. Disponible en http://revistas.uniandes.edu.co/doi/pdf/10.7440/histcrit63.2017.03

Prados de la Escosura, Leandro - Amaral, Samuel (edits.). La independencia americana: consecuencias económicas. Madrid: Alianza, 1993.

Pro Ruiz, Juan. "Ocultación de la riqueza rústica en España (1870-1936): acerca de la fiabilidad de las estadísticas sobre la propiedad y uso de la tierra". Revista de Historia económica, $\mathrm{n}^{\mathrm{o}} 1$, año XIII (1995), 89-114.

ROSF. Registro Oficial de la Provincia de Santa Fe, 12 tomos. Santa Fe: Tipografía de la Revolución, 1889.

Salvatore, Ricardo. "El imperio de la ley: delitos, estados y sociedad en la era rosista". Delito y Sociedad, $\mathrm{n}^{\circ}$ 4-5 (1993-1994), 93-118.

Santa Fe. Primer Censo General de la provincia de Santa Fe de 1887, República Argentina, América del sud, verificado bajo la administración del Dr. Gabriel Carrasco. Buenos Aires: Peuser, 1888.

Santilli, Daniel. "El papel de la tributación en la formación del Estado. La contribución directa en el siglo XIX en Buenos Aires". América Latina en la Historia Económica, $\mathrm{n}^{\circ} 33$ (2010), 31-61. Disponible en http://www.scielo.org.mx/scielo.php?script=sci_arttext\&pi $\mathrm{d}=\mathrm{S} 1405-22532010000100002$

Schmit, Roberto. "Las consecuencias económicas de la revolución en el Río de la Plata". En La historia económica y los procesos de independencia en la América hispana, editado por Bandieri, Susana. Buenos Aires: Prometeo libros, 2010, 71-104.

- Los límites del progreso: expansión rural en los orígenes del capitalismo rioplatense. Historia del capitalismo agrario pampeano, t. 5. Buenos Aires: Siglo XXI editores, 2008.

Sedeillán, Gisela. "Control social en la campaña bonaerense: la institución policial en Tandil, 1872-1900”. Ponencia en III Jornadas Nacionales Espacio, Memoria e Identidad, Rosario, 2004.

Tarragó, Griselda - Caula, Elsa. "Cuando el mañana sólo era desamparo: comerciantes rioplatenses en tiempos de guerra. 1806-1820". Prohistoria, año VII, nº 7 (2003), 41-80.

Tedeschi, Sonia. "Santa Fe en el litoral fluvial rioplatense. Los enlaces entre la economía y la política en época de revolución y guerra". En Historia económica del cono sur de América (Argentina, Bolivia, Brasil, Chile, Paraguay y Uruguay). La era de las revoluciones y la independencia, editada por Asdrúbal Silva, Hernán. México: Instituto Panamericano de Geografía e Historia, 2010, 697-733.

Vallejo Pousada, Rafael. "Reforma tributaria y regulación del delito fiscal en la España contemporánea (1830-1900)". Hacienda pública española, nº extra (1996), 135-150.

Zeballos, Estanislao. La región del trigo. Madrid: Hyspamerica, 1984. 